\title{
The role of pseudolysogeny in bacteriophage-host interactions in a natural freshwater environment
}

\author{
Steven Ripp and Robert V. Miller \\ Author for correspondence: Robert V. Miller. Tel: +14057447180. Fax : +14057446790. \\ e-mail : rum67@okway.okstate.edu
}

Department of

Microbiology and

Molecular Genetics,

Oklahoma State University,

Stillwater, OK 74078, USA

\begin{abstract}
Bacteriophages occur in high numbers in environmental ecosystems and are thus significant mediators of microbial survival and activities. However, interactions between microbial populations and phages in situ have been largely ignored. Current understanding of the process relies on studies performed with well-fed, laboratory-grown host bacteria. The purpose of the experiments reported here was to determine bacteriophage-host interactions under environmentally relevant conditions of nutrient limitation. These studies have revealed the importance of a phenomenon called pseudolysogeny in the maintenance of viral genetic material for extended periods of time in natural ecosystems. Pseudolysogeny is a form of phage-host cell interaction in which the nucleic acid of the phage resides within its starved host in an unstable, inactive state. It is hypothesized that pseudolysogeny occurs due to the cell's highly starved condition. In such cells, there is insufficient energy available for the phage to initiate genetic expression leading to either a true temperate response or to the lytic response. However, upon nutrient addition, the pseudolysogenic state is resolved, resulting in either the establishment of true lysogeny or the initiation of the lytic production of progeny virions. The pseudolysogenic state may explain the long-term survival of viruses in unfavourable environments in which the infective half-life of their virions is relatively short.
\end{abstract}

Keywords: pseudolysogeny, transduction, Pseudomonas aeruginosa, bacteriophage-host interactions, environmental microbiology

\section{INTRODUCTION}

Recent studies have documented extensive reservoirs of viral particles in natural ecosystems (Bergh et al., 1989; Bratbak \& Heldal, 1993; Hennes \& Suttle, 1995; Paul et al., 1991; Proctor \& Fuhrman, 1990; Walter et al., 1989). However, current knowledge of microbial and viral population dynamics does not support the production or the maintenance of large viral populations within natural environments. Our studies have directly addressed this discrepancy, by observing natural bacteriophage-host interactions under starvation conditions typically present in natural habitats. Morita (1993) has shown that the most important environmental factor affecting a natural microbial population is the availability of energy, and, since most ecosystems

Abbreviation: PBR, phage-to-bacterium ratio. are oligotrophic, energy resources are most often limiting. As a result, most bacteria in any given ecosystem are subsisting in a severely starved state. Roszak \& Colwell (1987) have referred to such cells as viable but nonculturable. In these cells basal metabolism is reduced to the lowest level of subsistence, and growth in any form is eliminated. Growth only occurs as blooms following the sporadic addition of energy to the ecosystem from some external source. It has been suggested that this is the normal state of bacterial populations in environmental ecosystems (Roszak \& Colwell, 1987).

Under starvation conditions, phage replication has been shown to be significantly altered, with latency periods being lengthened, burst sizes reduced, and the overall virulence of lytic viruses diminished (Kokjohn et al., 1991; Ogunseitan et al., 1990). In addition, the infective half-life of virions under natural conditions has been 
shown to be less than $48 \mathrm{~h}$ in most circumstances (Ogunseitan et al., 1990). Consequently, populations of free viral particles should remain fairly small. In actuality, they do not.

We have hypothesized that these large viral populations are due to a highly neglected phenomenon called pseudolysogeny. Pseudolysogeny was first described by Twort (1915) but not fully recognized until Romig \& Brodetsky (1961) used it to describe the relationship between various soil bacilli and their viruses. Pseudolysogeny describes a phage-host cell interaction in which the nucleic acid of the phage, upon infection of an appropriate host cell, neither establishes a long-term, stable relationship (i.e. lysogeny) nor elicits a lytic response. Rather, the phage nucleic acid simply resides within the cell in a non-active state. It is our hypothesis that due to the cell's highly starved condition, there is insufficient energy available for the phage to initiate either of these typical laboratory responses to infection. However, when the level of nutrient availability to the host cell increases, the phage acquires the necessary energy to allow gene expression, leading to either the establishment of a state of true lysogeny or replication and expression of the viral genome, leading to virion formation and lysis of the host cell.

We present in this paper a study of the pseudolysogenic response, under both laboratory and environmental conditions. Our studies suggest that pseudolysogeny may increase the effective environmental life of phage genomes well beyond the active infectious half-lives of their virions. Such an increase in genome survival may, in part, provide an explanation for the large environmental reservoirs of bacterial viruses commonly being observed.

\section{METHODS}

Bacterial strains and bacteriophage. Pseudomonas aeruginosa strains PAO1 (prototrophic) (Miller \& Ku, 1978) and PAO303 (argB21) (Kokjohn \& Miller, 1988) were used in this study. Phage UT1 was isolated from a natural freshwater source (Ogunseitan et al., 1990). It exhibits a virulent phenotype under laboratory conditions when host cells are well-fed, consistently entering into the lytic cycle. Under natural conditions, when host cells are starved, it appears pseudolysogenic (Kokjohn et al., 1991). It is also a generalized transducing phage (Ripp et al., 1994).

Media. Luria-Bertani (LB) agar plates were routinely used as a nonselective medium (Miller \& Ku, 1978). Selective medium consisted of Pseudomonas minimal medium (PMM) containing $0.4 \%$ glucose supplemented with arginine at $25 \mu \mathrm{g}$ $\mathrm{ml}^{-1}$ (Miller \& Ku, 1978).

Field site. Lakewater sampling and in situ incubations were performed at Lake Sanborn, a small (5 ha), semi-oligotrophic freshwater lake near Stillwater, OK, with a mean depth of approximately $2 \mathrm{~m}$ and very low abiogenic turbidity (Heath $\&$ Francko, 1988). Phosphate has been shown to be the limiting nutrient in this environment (Heath \& Francko, 1988; Nur \& Bates, 1979). Temperature $\left(25 \pm 3{ }^{\circ} \mathrm{C}\right), \mathrm{pH}(8 \pm 1)$, conductivity $(90 \pm 30 \mu \mathrm{S})$ and relevant weather conditions were determined at the time of each sampling.
Enumeration of bacteriophages by transmission electron microscopy. Phage enumeration from freshwater sources was performed as described by Bratbak \& Heldal (1993). Briefly, $100 \mathrm{ml}$ samples of lake water were preserved with $2 \%(\mathrm{v} / \mathrm{v})$ electron-microscope-grade formaldehyde immediately after sampling. Carbon-coated Formvar grids were taped onto a cellulose nitrate filter cut to fit within a Nalgene $38.5 \mathrm{ml}$ opentop, thick-wall polyallomer ultracentrifuge tube with a flat bottom moulded in epoxy glue. Samples were centrifuged at $12^{\circ} \mathrm{C}$ in a Beckman SW28 swinging-bucket rotor at $100000 \mathrm{~g}$ for $2.5 \mathrm{~h}$, after which the supernatant fluid was discarded and the grids gently removed. Grids were stained with $2 \%(\mathrm{w} / \mathrm{v})$ uranyl acetate for $30 \mathrm{~s}$ followed by a single rinse with sterile distilled water. After drying, the grids were examined in a JEOL Temscan 100CX transmission electron microscope.

\section{Microcosms}

Batch. Various experiments required progressive starvation of cells. This was accomplished by the use of batch cultures which consisted of 2 I Erlenmeyer flasks containing a variation of PMM in which the sodium citrate had been omitted $(\mathrm{PMM}-\mathrm{c})$. Yeast extract was provided as an initial nutrient source at a final concentration of $1 \times 10^{-5} \%$ (Replicon et al., 1995). Initial inoculants were grown overnight in LB broth at $37^{\circ} \mathrm{C}$, diluted $1 / 100$ in PMM-c supplemented with $0.5 \%$ yeast extract and grown to mid-exponential phase at $37^{\circ} \mathrm{C}$. These cultures were then washed twice with PMM-c (containing no yeast extract) and inoculated into the microcosm at the desired concentration. Incubations were done at room temperature with slow shaking (50 r.p.m.). Some microcosms were periodically spiked with yeast extract at a final concentration of $1 \times 10^{-5} \%$ to mimic random influxes of nutrients as might be expected in natural aquatic environments.

Chemostat. New Brunswick Bioflo model C30 bench-top chemostats were utilized in these experiments. Chemostats consisted of a 21 culture vessel and a 101 medium reservoir containing PMM-c. Yeast extract was provided as the sole nutrient source at a final concentration of $1 \times 10^{-5} \%$. Incubations were done at room temperature at an agitation rate of 200 r.p.m. The culture vessel was inoculated with PAO303 and phage UT1 at a multiplicity of infection of one (approximately $1 \times 10^{6}$ c.f.u. $\mathrm{ml}^{-1}$ and $1 \times 10^{6}$ p.f.u. $\mathrm{ml}^{-1}$ ). Inoculants were prepared as for the batch microcosms.

In situ incubated. Microcosms incubated in situ were prepared as described by Saye et al. (1990). One-litre Lifecell tissue culture chambers (Fenwal Laboratories) were filled with $500 \mathrm{ml}$ filter-sterilized $(0 \cdot 2 \mu \mathrm{m})$ lake water. Preparation and inoculation of strain PAO303 and phage UT1 were identical to those of the chemostat microcosms. The chambers were incubated in situ in Lake Sanborn either on the surface or at a depth of $2 \mathrm{~m}$. Some microcosms received periodic nutrient spikes of yeast extract at a final concentration of $1 \times 10^{-5} \%$.

Bacteriophage and infective centre enumerations. Phage counts were determined by filtering samples through $0.45 \mu \mathrm{m}$ syringe filters to remove bacterial cells. The remaining phages were then diluted and $0.1 \mathrm{ml}$ of the desired dilution combined with $0.1 \mathrm{ml}$ of PAO1 (in mid-exponential phase) and $2.5 \mathrm{ml} \lambda$ top agar (Miller \& Ku, 1978). This mixture was poured onto LB agar plates and the resulting p.f.u. were counted following overnight incubation at $37^{\circ} \mathrm{C}$.

Infective centres refer to bacteria which are in the latent period of lytic infection (Kokjohn et al., 1991). Enumeration of infective centres was carried out in the same manner as phage counts except that no initial filtration was performed. The titre of p.f.u. counts obtained from these plates represents the 
total number of both infective centres and free virions present in the sample. By subtracting the titre of free phages from this count, we obtained a number representing the concentration of infective centres (Kokjohn et al., 1991).

Identification of phage-releasing isolates. PAO303 cells were sampled from batch or in situ-incubated microcosms at various times and routinely examined to determine what percentage were activated to release phage virions. One hundred colonies per sample were replica-plated onto a top agar overlay of PAO1 and incubated overnight at $37^{\circ} \mathrm{C}$. A zone of lysis surrounding a colony was indicative of the spontaneous release of virions.

Colony hybridizations. Probes were constructed by isolating UT1 DNA according to Silhavy et al. (1984) and labelling with a Genius Nonradioactive Labelling Kit (Boehringer Mannheim Biochemicals). Colony hybridizations were performed to determine the frequency of cells harbouring phage DNA (preprophages). They were carried out as outlined in the Boehringer Genius system user's guide, version 2.0 (1992), using Magnagraph $0.45 \mu \mathrm{m}$ (mean pore size), $85 \mathrm{~mm}$ diameter nylon membranes (Micron Separations).

Time of nutrient spiking experiment. We wished to determine whether the timing of the nutrient spike had any effect on phage interaction with a starved host population. Submicrocosms were routinely removed from a main batch microcosm of PAO303 inoculated at $1 \times 10^{6}$ c.f.u. $\mathrm{ml}^{-1}$. To each submicrocosm, phage UT1 was added at $1 \times 10^{7}$ p.f.u. $\mathrm{ml}^{-1}$, allowed to infect for $8 \mathrm{~h}$, and then removed by centrifugation $(4000 \mathrm{~g}, 12 \mathrm{~min})$. Addition of phage was followed by an immediate nutrient spike, by a spike after $24 \mathrm{~h}$, or by no spike.

\section{RESULTS AND DISCUSSION}

\section{Relationship between degree of starvation and bacteriophage production}

We wished to investigate whether it was possible for bacteria in a starved state to interact with phages in a productive manner. We began our studies by evaluating the effects of long-term starvation on virion production. Batch cultures were inoculated with PAO303 at $4 \times 10^{6}$ c.f.u. $\mathrm{ml}^{-1}$ and phage UT1 at $1 \times 10^{5}$ p.f.u. $\mathrm{ml}^{-1}$, and incubated for approximately $80 \mathrm{~d}$. Some cultures were periodically spiked with nutrient while others were not spiked. This protocol simulated the feast-famine conditions which bacteria in freshwater environments typically encounter. Virion production and establishment of phage-releasing cells were found to be directly related to nutrient addition (Fig. 1). The control microcosm, held under strict starvation conditions, exhibited no substantial increases in the frequency of phages or phage-releasing cells within the population of bacteria. However, following nutrient addition, an identical culture showed pronounced increases, usually within approximately $12 \mathrm{~h}$ after each spike. The lack of phage production in the unspiked culture was not due to the inability of cells to become infected, since the frequency of phage-resistant cells remained undetectable during the entire incubation period. Phage-to-bacterium ratio (PBR) increases occurred only after nutrient addition and then slightly decreased due to the short half-life $(18 \mathrm{~h})$ of the phages under these conditions (Ogunseitan et al., 1990). The overall increase in the
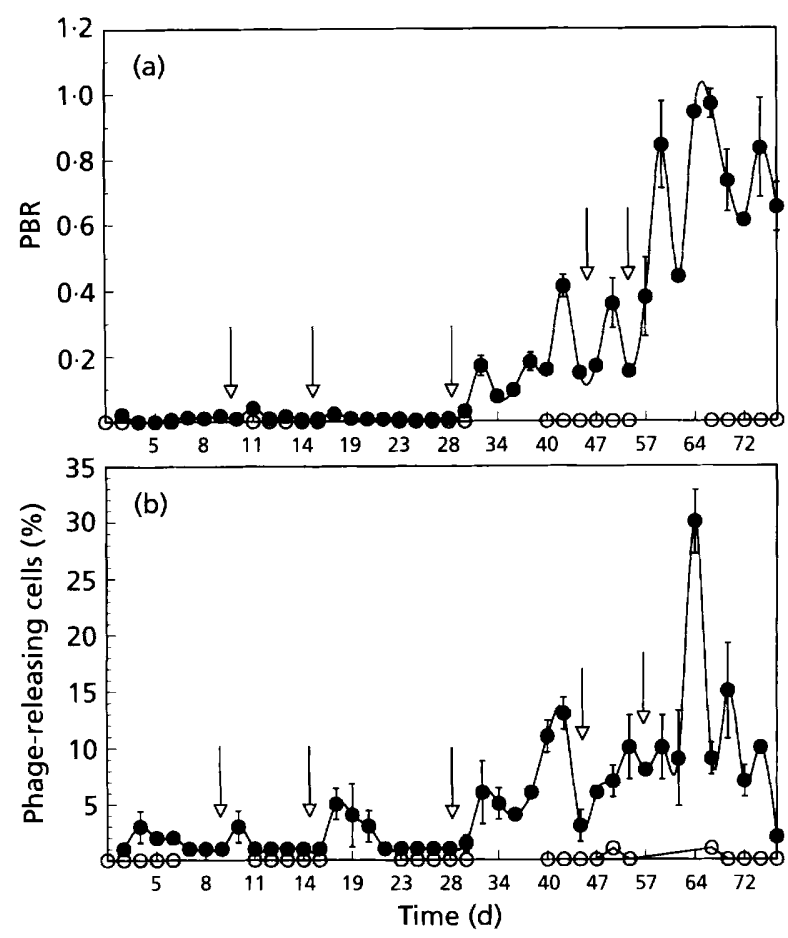

Fig. 1. (a) Phage-to-bacterium ratio (PBR) and (b) percentage of cells releasing phage in a microcosm containing PMM-C and yeast extract at $1 \times 10^{-5} \%$. Microcosms were inoculated with PAO303 and phage UT1 and spiked with nutrient $\left(1 \times 10^{-5} \%\right.$ yeast extract) at various intervals. Data in (a) and (b) are taken from the same microcosm. Points on the baseline in (a) represent PBRs of less than $10^{-3}$. Points on the baseline in (b) represent no phage-releasing cells detected. $O$. No nutrient added; 0 , nutrient added; 1 , time of nutrient addition. Error bars (not shown where smaller than symbol) represent SEM $(n=4)$.

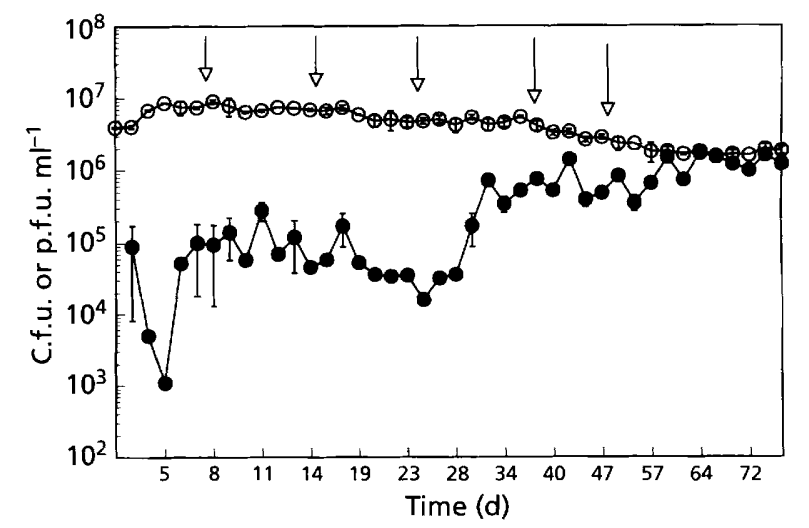

Fig. 2. Long-term starvation of a batch culture inoculated with $P$. aeruginosa strain PAO303 (O) and phage UT1 (O). Nutrient spikes of yeast extract $\left(1 \times 10^{-5} \%\right.$ final concentration) were added at times indicated by the arrows. Error bars represent $\operatorname{SEM}(n=4)$.

PBR was due in part to a gradual decrease in cell numbers (Fig. 2). However, the isolated peaks in PBR corresponded to elevated phage production following 

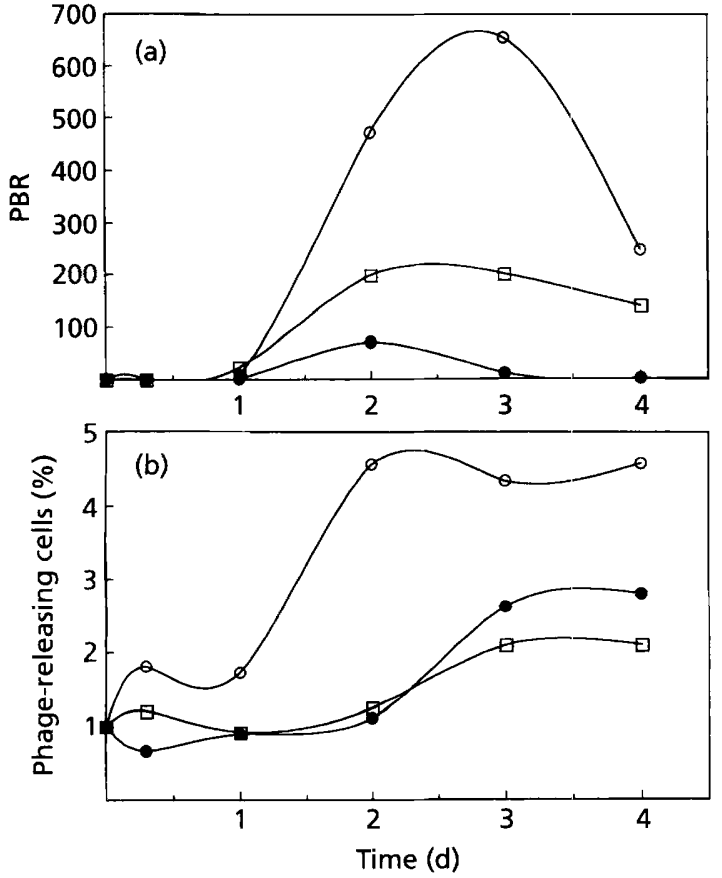

Fig. 3. Submicrocosm removed from a main batch culture inoculated with PAO303 and incubated for $25 \mathrm{~d}$ (day 0 represents day 25 of the main microcosm). (a) Phage-tobacterium ratio (PBR); (b) percentage of cells actively releasing phage. (All values divided by $t_{0}$ ). $O$. Phage UT1 was added $24 \mathrm{~h}$ after the submicrocosm was removed, allowed to infect for $6 \mathrm{~h}$, and then removed by centrifugation. Nutrient $\left(1 \times 10^{-5} \%\right.$ yeast extract) was added $24 \mathrm{~h}$ later. 0 , Phage UT1 was added and removed $6 \mathrm{~h}$ later as explained above; there was no nutrient addition. $\square$, Phage UT1 was added and removed $6 \mathrm{~h}$ later as explained above; nutrient was added at the same time as phage addition. Similar results were obtained in duplicate experiments.

nutrient spikes. These data illustrate that nutrient availability dramatically affects phage-host interactions.

\section{Effect of the time of nutrient spiking on starved cultures}

If our hypothesis is correct, pseudolysogenic phages should be activated by nutrient addition only when they are given the opportunity to first infect and maintain themselves within the starved cell. A phage infecting a well-fed cell should only exhibit lytic growth. This was shown to be true when phage UT1 was added to PAO303 submicrocosms followed by an immediate nutrient spike or a spike after $24 \mathrm{~h}$ (Fig. 3). Submicrocosms exhibited greatest virion production and frequency of phage-releasing bacteria when nutrient spiking occurred $24 \mathrm{~h}$ after phage inoculation (open circles). Infection with concurrent nutrient addition (open squares) led to only low levels of virion production, presumably because the phage could only sustain itself lytically in cells that simultaneously received nutrients. This is similar to what is seen when phage UT1 is grown under laboratory conditions using well-fed cells. In such a case, the virulent phenotype is
Table 1. Microcosm exhibiting the prevalence of cells that contain phage UT1 DNA but do not actively release phage (pseudolysogens) in an ideally starved chemostat culture

Data are presented as the fraction of cells that contain the phage genome, from which is derived the percentage of colonies actually shown to be releasing phage and the percentage of colonies not releasing phage but shown to contain phage DNA via colony hybridization.

\begin{tabular}{|cccc|}
\hline Day & $\begin{array}{c}\text { Fraction of cells } \\
\text { containing phage } \\
\text { genome }\end{array}$ & $\begin{array}{c}\text { Percentage } \\
\text { activated }^{* *}\end{array}$ & $\begin{array}{c}\text { Percentage not } \\
\text { activated }\end{array}$ \\
\hline 0 & $0 / 200$ & 0 & 0 \\
3 & $1 / 49$ & 0 & 100 \\
9 & $32 / 164$ & 17 & 83 \\
16 & $31 / 120$ & 32 & 68 \\
24 & $25 / 122$ & 35 & 65 \\
\hline
\end{tabular}

* Percentage of those cells which contain the phage genome that are either activated or not activated to release phage.

habitually observed (Kokjohn et al., 1991; Ogunseitan et al., 1990). When there was no nutrient addition (filled circles) phage production remained at a minimum since these cells did not possess the energy necessary to process the phage genome into an active lytic response.

\section{Chemostat microcosms}

Our first clear indication of the occurrence of a pseudolysogenic response was observed under continuous-culture conditions. Chemostats containing strain PAO303 and phage UT1 were incubated in $\mathrm{PMM}-\mathrm{c}$ for 1 month at a generation time (turnover time) of $10 \mathrm{~h}$. The total fraction of cells containing phage genomes (tested positive in colony hybridizations when probed with UT1 DNA) was compared to the fraction spontaneously releasing phage virions. We took the difference in these two numbers to represent the number of bacteria which contain a viral genome in the pseudolysogenic state (Table 1 ). Those releasing phage had most likely already undergone activation due to the added nutrient available to the host during growth of the colony on the plate. At all timepoints sampled, more colonies were shown to contain UT1 DNA than were actively releasing phage virions.

\section{Unstable propagation of preprophage}

If pseudolysogens did, in fact, contain phage genomes in which the preprophage had not yet been activated to replicate, one would predict that the majority of cells in a pseudolysogenic clone would not contain phage genomes at all. As in abortive transduction, the preprophage would be segregated into only one daughter cell without replicating (Arber, 1994). To test this hypothesis, pseudolysogenic colonies from the chemostat samples were streaked onto LB agar plates and the 
Table 2. Comparison of the percentage of phage-releasing cells ( $\%$ activated) to pseudolysogenic cells ( $\%$ not activated) in in situ-incubated microcosms residing on the lake surface or at a depth of $2 \mathrm{~m}$

The first column of each set lists the ratio of cells found to contain the phage genome. The second column represents the percentage of these cells actively releasing phage (' $\%$ act.'). The percentage of pseudolysogens, those cells not activated to release phage but shown to contain phage DNA, is recorded in the third column of each set ('\% not act.').

\begin{tabular}{|c|c|c|c|c|c|c|c|c|c|c|c|c|}
\hline \multirow[t]{3}{*}{ Day } & \multicolumn{6}{|c|}{ Top } & \multicolumn{6}{|c|}{ Bottom } \\
\hline & \multicolumn{3}{|c|}{ Chamber 1} & \multicolumn{3}{|c|}{ Chamber 2} & \multicolumn{3}{|c|}{ Chamber 3} & \multicolumn{3}{|c|}{ Chamber 4} \\
\hline & $\begin{array}{l}\text { Fraction } \\
\text { of cells } \\
\text { containing } \\
\text { phage } \\
\text { genome }\end{array}$ & $\begin{array}{c}\% \\
\text { act. }\end{array}$ & $\begin{array}{c}\% \\
\text { not act. }\end{array}$ & $\begin{array}{c}\text { Fraction of } \\
\text { cells } \\
\text { containing } \\
\text { phage } \\
\text { genome }\end{array}$ & $\begin{array}{c}\% \\
\text { act. }\end{array}$ & $\begin{array}{c}\% \\
\text { not act. }\end{array}$ & $\begin{array}{l}\text { Fraction of } \\
\text { cells } \\
\text { containing } \\
\text { phage } \\
\text { genome }\end{array}$ & $\begin{array}{c}\% \\
\text { act. }\end{array}$ & $\begin{array}{c}\% \\
\text { not act. }\end{array}$ & $\begin{array}{c}\text { Fraction of } \\
\text { cells } \\
\text { containing } \\
\text { phage } \\
\text { genome }\end{array}$ & $\begin{array}{c}\% \\
\text { act. }\end{array}$ & $\begin{array}{c}\% \\
\text { not act. }\end{array}$ \\
\hline 0 & $0 / 170$ & 0 & 0 & $0 / 108$ & 0 & 0 & $0 / 310$ & 0 & 0 & $0 / 198$ & 0 & 0 \\
\hline 9 & $6 / 310$ & 0 & 100 & $0 / 140$ & 0 & 0 & $0 / 220$ & 0 & 0 & $6 / 430$ & 0 & 100 \\
\hline 15 & $247 / 570$ & 51 & 49 & $187 / 740$ & 92 & 8 & $65 / 140$ & 74 & 26 & $30 / 720$ & 25 & 75 \\
\hline 21 & $350 / 570$ & 92 & 8 & $360 / 420$ & 74 & 26 & $280 / 520$ & 94 & 6 & $40 / 370$ & 100 & 0 \\
\hline 27 & $300 / 480$ & 100 & 0 & $15 / 109$ & 64 & 36 & $244 / 280$ & 100 & 0 & $223 / 740$ & 80 & 20 \\
\hline 29 & $490 / 650$ & 93 & 7 & $310 / 440$ & 93 & 7 & $224 / 610$ & 81 & 19 & $153 / 300$ & 78 & 22 \\
\hline 43 & $64 / 86$ & 84 & 16 & $112 / 112$ & 82 & 18 & $236 / 400$ & 92 & 8 & $68 / 83$ & 93 & 7 \\
\hline
\end{tabular}

resulting individual colonies were probed with UT1 DNA. The results indicated that only a small fraction of cells within a pseudolysogenic colony contained phage DNA. The preprophage seemed to undergo haphazard transfer during cell division. These data indicate that the phage nucleic acid had stabilized itself in the host cell in a form that does not allow fidelity of scheduled DNA replication coordinate with host genome replication and cell division.

\section{Phage enumeration from a freshwater source}

Previous studies have reported phage abundance in rivers and ocean waters to range from $10^{3}$ to $10^{8}$ particles $\mathrm{ml}^{-1}$ (Bergh et al., 1989; Hennes \& Suttle, 1995; Paul et al., 1991; Walter et al., 1989). We wished to validate the presence of significant phage populations at our freshwater-lake field site, a small (5 ha) oligotrophic natural lake. Samples of lake water were prepared for phage enumerations as described above, and phage particles from each sample were counted within 100 transmission electron microscope view fields. An average of $4 \cdot 1( \pm 0 \cdot 4) \times 10^{6}$ virus particles per $\mathrm{ml}$ of lake water were observed. These data are consistent with the work of Replicon et al. (1995), who observed concentrations of $1 \times 10^{4}$ p.f.u. exclusively infective for $P$. aeruginosa per $\mathrm{ml}$ in a freshwater lake near Chicago, IL, USA. PBRs in these samples were as high as 50:1, implying that most of the bacteria in the environment were infected with phages. Proctor \& Fuhrman (1990) used electron microscopy to estimate levels of phage infection in a marine environment. They concluded that as many as $70 \%$ of the cells in ocean waters were infected with phages at any one time. More recently,
Suttle (1994) estimated that up to $50 \%$ of the marine microbial population must be lysed per day to maintain the phage levels observed in the marine environment.

\section{In situ-incubated microcosms}

To study pseudolysogeny in a condition closer to a true environmental situation, we incubated microcosms in situ. Filter-sterilized water from Lake Sanborn was used to prepare four microcosms, each inoculated with PAO303 and phage UT1. These were incubated in the lake either on the surface or at a depth of $2 \mathrm{~m}$. Yeast extract was periodically added to half of the microcosms.

Microcosms displayed high concentrations of cells containing UT1 DNA, not all of which actively released phage virions (Table 2). Those not activated were considered to be in a pseudolysogenic state. The addition of nutrient did not produce the expected sharp increases in PBR numbers as was exhibited in the in vitro incubated microcosms (Fig. 2). This was probably due to the fact that a sufficient influx of nutrients from the in situ lakewater environment into the microcosms occurred such that the small addition of yeast extract had little or no measurable effect.

\section{Concluding remarks}

In this study, we have shown that pseudolysogenic associations between phages and their hosts have the potential to affect natural phage ecology dramatically. As a result of sequestering of phage genomes in the pseudolysogenic state, effective phage half-lives are 
greatly increased, leading to the long-term survival of viruses that would otherwise be eliminated from the environment. Pseudolysogeny is likely to be an important factor in maintenance of the large phage populations observed in aquatic environments, especially those that appear virulent under laboratory conditions.

Phages affect microbial ecosystems in at least two potentially significant ways. First, they act as bacterial predators, influencing various environmental food webs (Proctor \& Fuhrman, 1990). Second, previous studies from our laboratory have shown that transduction, the viral-mediated horizontal transfer of genetic material, is a significant gene exchange mechanism among bacteria in natural aquatic ecosystems, capable of influencing genetic diversity and evolution (Replicon et al., 1995; Ripp et al., 1994; Saye et al., 1990). Transduction potentially plays a substantial role in the estimation of the efficacy and associated risks of applying genetically engineered micro-organisms to natural environments. The potential of virulent phages to form pseudolysogenic relationships must be considered in estimating exposure of natural populations to introduced genetic sequences. Genetic material contained in preprophage genomes will have a longer half-life in the environment than will infective virions of the virus. Thus, estimates of exposure duration must be adjusted to account for the pseudolysogenic phenomenon. Further studies will allow for the necessary development of predictive models of true phage-host interactions in oligotrophic environmental ecosystems.

\section{ACKNOWLEDGEMENTS}

This study was supported by cooperative agreement CR 820060 with the US EPA Environmental Research Laboratory, Gulf Breeze, FL, USA.

\section{REFERENCES}

Arber, W. (1994). Bacteriophage transduction. In Encyclopedia of Virology, vol. 1, pp. 107-113. Edited by R. G. Webster \& A. Granoff. London: Academic Press.

Bergh, O., Borsheim, K. Y., Bratback, G. \& Heldal, M. (1989). High abundance of viruses found in aquatic environments. Nature $\mathbf{3 4 0}$, $467-468$.

Bratbak, G. \& Heldal, M. (1993). Total count of viruses in aquatic environments. In Handbook of Methods in Aquatic Microbial Ecology, pp. 135-138. Edited by P. Kemp, B. F. Sherr, E. B. Sherr \& J. J. Cole. Boca Raton, FL: Lewis Publishers.

Heath, R. T. \& Francko, D. A. (1988). Comparison of phosphorus dynamics in two Oklahoma reservoirs and a natural lake varying in abiogenic turbidity. Can J Fish Aquat Sci 45, 1480-1486.

Hennes, K. P. \& Suttle, C. A. (1995). Direct counts of viruses in natural waters and laboratory cultures by epifluorescence microscopy. Limnol Oceanogr 40, 1050-1055.
Kokjohn, T. A. \& Miller, R. V. (1988). Characterization of the Pseudomonas aeruginosa recA gene: the Les phenotype. $J$ Bacteriol 170, 578-581.

Kokjohn, T. A., Sayler, G. S. \& Miller, R. V. (1991). Attachment and replication of Pseudomonas aeruginosa bacteriophages under conditions simulating aquatic environments. J Gen Microbiol 137, 661-666.

Miller, R. V. \& Ku, C. M. C. (1978). Characterization of Pseudomonas aeruginosa mutants deficient in the establishment of lysogeny. J Bacteriol 134, 875-883.

Morita, R. Y. (1993). Starvation-survival strategies in bacteria. In Handbook of Methods in Aquatic Microbial Ecology, pp. 441-445. Edited by P. Kemp, B. F. Sherr, E. B. Sherr \& J. J. Cole. Boca Raton, FL: Lewis Publishers.

Nur, R. \& Bates, M. H. (1979). The effects of $\mathrm{pH}$ on the aluminum, iron and calcium phosphate fractions of lake sediments. Water Res 13, 813-815.

Ogunseitan, O. A., Sayler, G. S. \& Miller, R. V. (1990). Dynamic interactions of Pseudomonas aeruginosa and bacteriophages in lakewater. Microb Ecol 19, 171-185.

Paul, J. H., Jiang, S. C. \& Rose, J. B. (1991). Concentration of viruses and dissolved DNA from aquatic environments by vortex flow filtration. Appl Environ Microbiol 57, 2197-2204.

Proctor, L. M. \& Fuhrman, J. A. (1990). Viral mortality of marine bacteria and cyanobacteria. Nature 343, 60-62.

Replicon, J., Frankfater, A. \& Miller, R. V. (1995). A continuous culture model to examine factors that affect transduction among Pseudomonas aeruginosa strains in freshwater environments. Appl Environ Microbiol 61, 3359-3366.

Ripp, S., Ogunseitan, O. A. \& Miller, R. V. (1994). Transduction of a freshwater microbial community by a new Pseudomonas aeruginosa generalized transducing phage, UT1. Mol Ecol 3, 121-126.

Romig, W. R. \& Brodetsky, A. M. (1961). Isolation and preliminary characterization of bacteriophages for Bacillus subtilis. J Bacteriol 82, 135-141.

Roszak, D. B. \& Colwell, R. R. (1987). Survival strategies of bacteria in the natural environment. Microbiol Rev 51, 365-379.

Saye, D. J., Ogunseitan, O. A., Sayler, G. S. \& Miller, R. V. (1990). Transduction of linked chromosomal genes between Pseudomonas aeruginosa during incubation in situ in a freshwater habitat. Appl Environ Microbiol 56, 140-145.

Silhavy, T. J., Berman, M. L. \& Enquist, L. W. (1984). Experiments with Gene Fusions. Cold Spring Harbor, NY: Cold Spring Harbor Laboratory.

Suttle, C. A. (1994). The significance of viruses to mortality in aquatic microbial communities. Microb Ecol 28, 237-243.

Twort, F. W. (1915). An investigation on the nature of ultramicroscopic viruses. Lancet 2, 1241-1243.

Walter, R., Macht, W., Durkop, J., Hecht, R., Hornig, U. \& Schulze, P. (1989). Virus levels in river waters. Water Res 23, 133-138.

Received 13 September 1996; revised 20 January 1997; accepted 6 February 1997. 